\title{
Phytoremediation potential of wild plants growing on soil contaminated with heavy metals
}

\author{
Vladica Čudić ${ }^{1}$, Dragoslava Stojiljković ${ }^{2}$ and Aleksandar Jovović \\ PWW d.o.o., Niš ${ }^{1}$, University of Belgrade, Faculty of Mechanical Engineering, Belgrade ${ }^{2}$, Serbia
}

[Received in May 2016; CrossChecked in May 2016; Accepted in September 2016]

\begin{abstract}
Phytoremediation is an emerging technology that employs higher plants to cleanup contaminated environments, including metal-polluted soils. Because it produces a biomass rich in extracted toxic metals, further treatment of this biomass is necessary. The aim of our study was to assess the five-year potential of the following native wild plants to produce biomass and remove heavy metals from a polluted site: poplar (Populus ssp.), ailanthus (Ailanthus glandulosa L.), false acacia (Robinia pseudoacacia L.), ragweed (Artemisia artemisiifolia L.), and mullein (Verbascum thapsus L). Average soil contamination with $\mathrm{Pb}, \mathrm{Cd}, \mathrm{Zn}, \mathrm{Cu}, \mathrm{Ni}, \mathrm{Cr}$, and As in the root zone was $22,948.6 \mathrm{mg} \mathrm{kg}^{-1}, 865.4 \mathrm{mg} \mathrm{kg}^{-1}, 85,301.7 \mathrm{mg} \mathrm{kg}^{-1}$, $3,193.3 \mathrm{mg} \mathrm{kg}^{-1}, 50.7 \mathrm{mg} \mathrm{kg}^{-1}, 41.7 \mathrm{mg} \mathrm{kg}^{-1}$, and $617.9 \mathrm{mg} \mathrm{kg}^{-1}$, respectively. We measured moisture and ash content, concentrations of $\mathrm{Pb}, \mathrm{Cd}, \mathrm{Zn}, \mathrm{Cu}, \mathrm{Ni}, \mathrm{Cr}$, and $\mathrm{As}$ in the above-ground parts of the plants and in ash produced by combustion of the plants, plus gross calorific values. The plants' phytoextraction and phytostabilisation potential was evaluated based on their bioconcentration factor (BCF) and translocation factor (TF). Mullein was identified as a hyperaccumulator for Cd. It also showed a higher gross calorific value $\left(19,735 \mathrm{~kJ} \mathrm{~kg}^{-1}\right)$ than ragweed $\left(16,469 \mathrm{~kJ} \mathrm{~kg}^{-1}\right)$. The results of this study suggest that mullein has a great potential for phytoextraction and for biomass generation, and that ragweed could be an effective tool of phytostabilisation.
\end{abstract}

KEY WORDS: arsenic; bioconcentration factor; biomass; cadmium; chromium; copper; hyperaccumulator; lead; mullein; nickel; phytoextraction; phytostabilisation; ragweed; rhizosphere; translocation factor; zinc

Heavy metals from various sources, including old smelters, could seriously affect the surrounding environment, enter the food chain, and affect human health $(1,2)$. The most severe cases of pollution have been associated with mining, processing, and dumping of heavy metals (3-5). A case in point is the production of zinc. Primary zinc production can not completely separate many of the trace elements from jarosite sludge. Since the early 1980s, waste jarosite sludge has been a major problem in BudelDorpleinin the southeastern part of the Netherlands, where one of the world's largest zinc production facilities is situated. It has four isolated tailing ponds receiving about 120,000 tonnes of jarosite waste a year. Yet, intensive cadmium pollution of the gardens in and around BudelDorplein was recorded in the 1980s (6), mainly due to pyrometallurgical zinc production.

Unselective waste disposal on soil can lead to a significant increase in a wide range of metals such as arsenic $(\mathrm{As})$, cadmium $(\mathrm{Cd})$, chromium $(\mathrm{Cr})$, nickel $(\mathrm{Ni})$, copper $(\mathrm{Cu})$, lead $(\mathrm{Pb})$ and zinc $(\mathrm{Zn})$. This waste, however, is further modified by chemical and biological processes (7). How shall these metals affect the food chain depends on the source, metal levels, soil characteristics, plant uptake and animal absorption (8).

Correspondence to: Vladica Čudić, PWW d.o.o. 25. maj 65b, 18000 Niš, Serbia; E-mail: vladicacudic@gmail.com
Phytoremediation is the use of plants to ameliorate contaminated soils. Vegetative cover on a soil polluted with heavy metals may prevent the dispersion of contaminants by the wind erosion and reduce the volume of water percolating through the soil. This could keep contaminants away from the underlying ground water by stabilising them in the soil profile (9). In extreme cases, such as mine spoils, revegetation of contaminated soils may be difficult due to the phytotoxicity of heavy metals and may require the use of metal-tolerant plants. Phytotoxicity in plants varies with the plant and heavy metal: for $\mathrm{Zn}$ it ranges between 500 and $1,500 \mathrm{mg} \mathrm{kg}^{-1}(10,11)$, for $\mathrm{Pb}$ it is about $300 \mathrm{mg} \mathrm{kg}^{-1}$ (11), for $\mathrm{Cu}$ is from 25 to $40 \mathrm{mg} \mathrm{kg}^{-1}(10,11)$, for $\mathrm{Cd}$ from 5 to $700 \mathrm{mg} \mathrm{kg}^{-1}$ (10), for As from 3 to $10 \mathrm{mg} \mathrm{kg}^{-1}$ (10), for Ni up to $100 \mathrm{mg} \mathrm{kg}^{-1}$ (10), and for Cr from 6 to $100 \mathrm{mg} \mathrm{kg}^{-1}(12)$.

Hyperaccumulators are plants that can accumulate exceptionally high amounts of metals. Baker and Brooks (13) reported the following metal concentrationsin the tissues of different hyperaccumulators: $100 \mathrm{mg} \mathrm{kg}^{-1}$ for $\mathrm{Cd}$, $1,000 \mathrm{mg} \mathrm{kg}^{-1}$ for $\mathrm{Ni}, \mathrm{Cu}, \mathrm{Co}$, and $\mathrm{Pb}$, and $10,000 \mathrm{mg} \mathrm{kg}^{-1}$ for $\mathrm{Zn}$ and $\mathrm{Mn}$.

Plants take up mobile metals and other contaminants into their above-ground parts, which can then be removed by harvesting/coppicing (phytoextraction). At the same time, plant roots prevent the migration of heavy metal ions through the soil profiles into the groundwater and limit their availability and toxic effects on other plants and organisms, 
which is called phytostabilisation $(14,15)$. Litter and vegetation covers reduce leaching by increasing waterstorage capacity of the soil and evapotranspiration (16), and the roots control erosion, create an aerobic environment in the rhizosphere, add organic matter that increases soil aggregation, and bind the contaminants (17). Immobilisation of trace elements in both coarse and fine roots can also reduce leaching, particularly of $\mathrm{Cu}$ and $\mathrm{Zn}$, but also of As and $\mathrm{Pb}(18)$.

It is important to use native plants for phytoremediation because these plants are often better in terms of survival, growth, and reproduction under environmental stress than plants introduced from other environments.

Phytoremediation has been questioned as a method for remediation of soils contaminated with heavy metals because the biomass it produces contains as much as $4 \%$ of heavy metals per unit of dry biomass, which calls for further treatment before this biomass can be used for a variety of purposes $(19,20)$. Some metals, such as Ni, Zn, and $\mathrm{Cu}$ can be recovered from waste ash and re-used. Ash obtained from combustion of biomass contaminated with heavy metals can contain up to $30 \%$ of total metals, which is several times more than the concentration of metals in ores. Therefore, this bio-ash (or bio-ore) is a rich source of metals that can be extracted, depending on the profitability of processing and the actual metal levels (21).

Considering the potential uses and issues associated with phytoremediation, the aim of this study was to see which of the five native wild plants to our area had a high phytoremediation potential in terms of both phytoextraction and phytostabilisation and to determine their production of biomass and the concentrations of heavy metals and arsenic. Our secondary aim was to evaluate the potential of ragweed and mullein biomass as an energy source.

\section{MATERIALS AND METHODS}

\section{Site characterisation}

This study was conducted at the landfill of a zinc processing factory that is currently undergoing reconstruction (Figure 1).The landfill is located near Šabac in west Serbia, $85 \mathrm{~km}$ from Belgrade and 50 to $200 \mathrm{~m}$ from the Sava River $\left(44^{\circ} 44^{\prime} 47.41^{\prime \prime} \mathrm{N}, 19^{\circ} 43^{\prime} 16.56^{\prime \prime} \mathrm{E}\right)$. The soil is geologically classified (22) as loamy soil (Table 1). The total studied site area was about $45,000 \mathrm{~m}^{2}$. The landfill was in use from 1955 to 2006 and had primarily been receiving jarosite sludge, which was disposed of directly on the land and mixed with soil in layers. The composition of the deposited jarosite sludge, according to the process designed in the factory, was: 3-5 \% Zn, 30-32 \% Fe, 2-2.5\% Pb, $0.004 \% \mathrm{Cu}$, and $4 \%$ water. The sludge layer mixed with soil was approximately $2 \mathrm{~m}$ thick, and its total volume was around $15,500 \mathrm{~m}^{3}$.

The climate in the region is temperate continental, characterised by an annual average temperature of $11.5^{\circ} \mathrm{C}$ and average precipitation of 650 to $950 \mathrm{~mm}$ (23). The vegetation period ranges from 240 to 260 days. At the moment, very few wild plant species exist on the site. The plant species collected for this research belong to the community of plants native to the sampling site and include the poplar (Populus ssp.), ailanthus (Ailanthus glandulosa L.), false acacia (Robinia pseudoacacia L.), ragweed (Artemisia artemisiifolia L.), and mullein (Verbascum thapsus L.). In addition, we sampled soil from an uncontaminated area in Šabac (4443'74.40" N, 1945'73.90" E) and plants from an uncontaminated area in Belgrade $\left(44^{\circ} 46^{\prime} 16.00^{\prime \prime} \mathrm{N}, 20^{\circ} 25^{\prime} 36.00^{\prime \prime} \mathrm{E}\right)$ for control. In the first

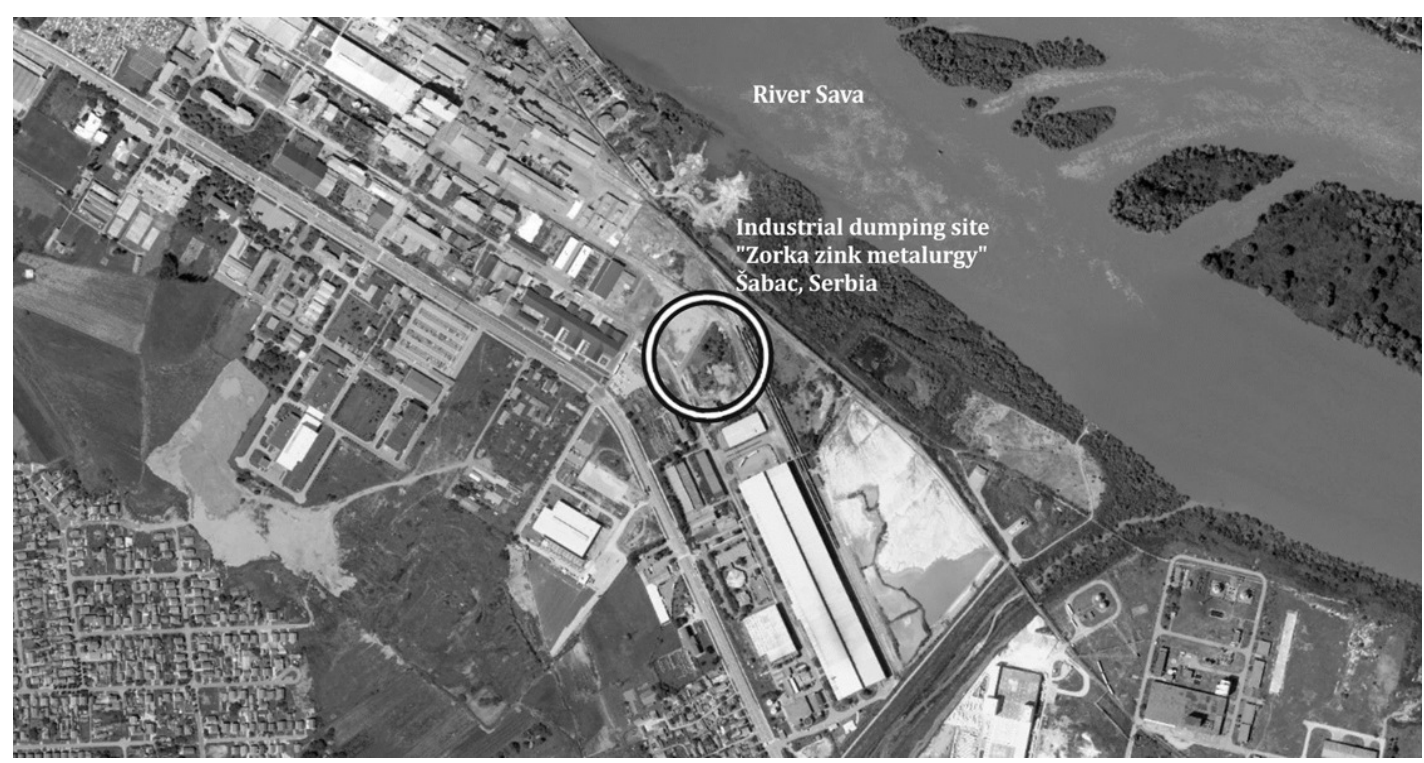

Figure 1 Study location 
Table 1 Soil composition at the industrial waste landfill site owned by the zinc production and processing factory Zorka Non-Ferrous Metallurgy Joint Stock Company, Šabac, Serbia (22)

\begin{tabular}{|c|c|c|c|c|c|}
\hline \multicolumn{6}{|c|}{ Soil structure (\%) } \\
\hline $\begin{array}{c}\text { Coarse fragments } \\
>\mathbf{2} \mathrm{mm} \text { including gravel } \\
\text { and stones }\end{array}$ & $\begin{array}{c}\text { Sand } \\
2.0-0.05 \mathrm{~mm}\end{array}$ & $\begin{array}{c}\text { Sludge } \\
0.05-0.002 \mathrm{~mm}\end{array}$ & $\begin{array}{c}\text { Clay } \\
<0.0002 \mathrm{~mm}\end{array}$ & $\mathrm{CaCO}_{3}$ & Organic C \\
\hline 39.69 & 39.51 & 14.56 & 5.97 & 3.74 & 1.41 \\
\hline
\end{tabular}

year of the study, control soil samples were taken from an uncontaminated area in Belgrade.

Soils and plants had been sampled over four visits in five years (for details see Table 2).

\section{Soil sampling and analysis}

Soils were sampled from the rhizosphere at the depth of to $25 \mathrm{~cm}$, air-dried, and sieved through a 2-mm mesh. They were composites of 20-25 individual random portions mixed together. The samples were analysed for total concentration for six heavy metals $(\mathrm{Cr}, \mathrm{Cu}, \mathrm{Zn}, \mathrm{Ni}, \mathrm{Cd}$, and $\mathrm{Pb}$ ) and arsenic (As), based on the landfill site characterisation from the first year of research. To determine the concentrations of heavy metals and arsenic, $1 \mathrm{~g}$ of a solid sample digested by repeatedly adding portions of concentrated nitric acid $\left(\mathrm{HNO}_{3}\right)$ concentrated hydrochloric acid $(\mathrm{HCl})$ and $30 \%$ hydrogen peroxide $\left(\mathrm{H}_{2} \mathrm{O}_{2}\right)(24)$. The acid-digested samples were then analysed for $\mathrm{Cd}, \mathrm{Cr}, \mathrm{Cu}$, $\mathrm{Ni}, \mathrm{Pb}$, and $\mathrm{Zn}$ using inductively coupled plasma optical emission spectrometry (ICP-OES, Varian Vista-PRO, Varian, Mulgrave, Australia) $(25,26)$ or flame atomic absorption spectrophotometry (Varian SPECTRAA-200). For As analysis we used hydride generation atomic absorption spectrometry (Varian SPECTRAA20+) equipped with a hydride generation unit (Agilent vapour generation accessory VGA 77, Santa Clara, CA, USA) (27).

During digestion, three quality-assurance samples (a blank, a duplicate, and a spike) were included with every 12 samples. Analytical blanks and calibration standards were included with every 10 samples for quality control. The recoveries from spiked soil samples ranged from 93.6 to $98.7 \%$, and the overall accuracy was $100 \pm 20 \%$. For quality assurance and control we used certified reference soil (Certificate Set of Czech certified reference materials 7001, 7002, 7003, 7004) from the Czech Metrological Institute, Brno.

\section{Plant material and ash analyses}

Plants were collected from polluted and control areas during four visits at different times of the year over five years as detailed in Table 2.

After collection, the plants were divided into root and above-ground parts and washed gently with deionised water for approximately $5 \mathrm{~min}$ to remove the adhering soil particles. Washed plant parts were air-dried at room temperature for two weeks. Then we prepared biomass samples; those cut into particles smaller than $30 \mathrm{~mm}$ were used to determine total moisture content, those milled to particle sizes of less than $1 \mathrm{~mm}$ were burnt and used to determine ash metal and As content and the calorific value, and those mashed and ground to particle sizes of less than $250 \mu \mathrm{m}$ were used for chemical analysis (28).

In order to evaluate the phytoextraction potential of the wild plants we calculated the bioconcentration factor (BCF) and the translocation factor (TF), as follows:

$$
\begin{aligned}
& \mathrm{BCF}=\mathrm{C}_{\text {roots }} \mathrm{C}_{\text {soil }}^{-1} \\
& \mathrm{TF}=\mathrm{C}_{\text {shoots }} \mathrm{C}_{\text {roots }}^{-1}
\end{aligned}
$$

Where $\mathrm{C}_{\text {roots }}$ is the metal mass fractionin the root $\left(\mathrm{mg} \mathrm{kg}^{-1}\right)$, $\mathrm{C}_{\text {soil }}$ is the metal level in the rhizosphere $\left(\mathrm{mg} \mathrm{kg}^{-1}\right)$, and $\mathrm{C}_{\text {shoots }}$ is the metal level in the above-ground parts of the plants (plant shoots) $\left(\mathrm{mg} \mathrm{kg}^{-1}\right)$.

The ash produced by biomass combustion is essential for the selection of appropriate combustion and waste gas treatment technologies (21). The ash content obtained by the combustion of biomass was determined for ragweed and mullein in relation to two combustion temperatures: $550{ }^{\circ} \mathrm{C}(29)$ and $815^{\circ} \mathrm{C}(30)$. Biomass calorific value (CV) was measured in terms of energy per unit of mass $\left(\mathrm{kJ} \mathrm{kg}^{-1}\right)$ (31). The plant biomass samples were burnt in an oxygen bomb calorimeter $(32,33)$, and the obtained ash samples analysed for total $\mathrm{Cr}, \mathrm{Cu}, \mathrm{Zn}, \mathrm{Ni}, \mathrm{Cd}, \mathrm{Pb}$, and $\mathrm{As}$.

Plant and ash samples were digested in the same way as soil samples (24). Total metal content was measured using the flame atomic absorption spectrometry and ICPOES, and As was measured using the hydride generation, as described above.

\section{RESULTS AND DISCUSSION}

\section{Soil pollution and wild plant analyses}

Table 3 shows significant contamination of landfill soil, with $\mathrm{Pb}, \mathrm{Cd}, \mathrm{Cu}, \mathrm{Zn}, \mathrm{Ni}, \mathrm{Cr}$, and As levels substantially higher than the regulation limits (34) for Serbia (Table 3). The control soil from Belgrade had a slightly higher levels of Ni than the polluted soil (Table 3), which confirms earlier findings that this control area is generally rich in $\mathrm{Ni}$ (35) 
Table 2 Soil and plant sampling design

\begin{tabular}{|c|c|c|c|}
\hline Year & Soil type & Soil sample & Plant sample \\
\hline \multirow{6}{*}{$\begin{array}{l}\text { I second } \\
\text { quarter }\end{array}$} & \multirow{3}{*}{$\begin{array}{l}\text { Contaminated soil- } \\
\text { Šabac* }\end{array}$} & \multirow{3}{*}{$\begin{array}{l}\text { Composite sample from the } \\
\text { rhizosphere }\end{array}$} & Ragweed - aboveground \\
\hline & & & False acacia- aboveground \\
\hline & & & Ailanthus - aboveground \\
\hline & \multirow{3}{*}{ Control soil - Belgrade** } & \multirow{3}{*}{$\begin{array}{l}\text { Composite sample from the } \\
\text { rhizosphere }\end{array}$} & Ragweed - aboveground \\
\hline & & & False acacia- aboveground \\
\hline & & & Ailanthus- aboveground \\
\hline \multirow{10}{*}{ II third quarter } & \multirow{10}{*}{$\begin{array}{l}\text { Contaminated soil- } \\
\text { Šabac* }\end{array}$} & \multirow{2}{*}{$\begin{array}{l}\text { Composite sample from the } \\
\text { rhizosphere of ragweed }\end{array}$} & Ragweed - aboveground \\
\hline & & & Ragweed- root \\
\hline & & \multirow{2}{*}{$\begin{array}{l}\text { Composite sample from the } \\
\text { rhizosphere of false acacia }\end{array}$} & False acacia- aboveground \\
\hline & & & False acacia - root \\
\hline & & \multirow{2}{*}{$\begin{array}{l}\text { Composite sample from the } \\
\text { rhizosphere of ailanthus }\end{array}$} & Ailanthus - aboveground \\
\hline & & & Ailanthus - root \\
\hline & & \multirow{2}{*}{$\begin{array}{l}\text { Composite sample from the } \\
\text { rhizosphere of mullein }\end{array}$} & Mullein - aboveground \\
\hline & & & Mullein - root \\
\hline & & \multirow{2}{*}{$\begin{array}{l}\text { Composite sample from the } \\
\text { rhizosphere of poplar }\end{array}$} & Poplar- aboveground \\
\hline & & & Poplar - root \\
\hline \multirow{10}{*}{$\begin{array}{l}\text { III fourth } \\
\text { quarter }\end{array}$} & \multirow{10}{*}{$\begin{array}{l}\text { Contaminated soil- } \\
\text { Šabac* }\end{array}$} & \multirow{2}{*}{$\begin{array}{l}\text { Composite sample from the } \\
\text { rhizosphere of ragweed }\end{array}$} & Ragweed- aboveground \\
\hline & & & Ragweed - root \\
\hline & & \multirow{2}{*}{$\begin{array}{l}\text { Composite sample from the } \\
\text { rhizosphere of false acacia }\end{array}$} & False acacia- aboveground \\
\hline & & & False acacia - root \\
\hline & & \multirow{2}{*}{$\begin{array}{l}\text { Composite sample from the } \\
\text { rhizosphere of ailanthus }\end{array}$} & Ailanthus - aboveground \\
\hline & & & Ailanthus - root \\
\hline & & \multirow{2}{*}{$\begin{array}{l}\text { Composite sample from the } \\
\text { rhizosphere of mullein }\end{array}$} & Mullein - aboveground \\
\hline & & & Mullein- root \\
\hline & & \multirow{2}{*}{$\begin{array}{l}\text { Composite sample from the } \\
\text { rhizosphere of poplar }\end{array}$} & Poplar- aboveground \\
\hline & & & Poplar - root \\
\hline \multirow{11}{*}{$\begin{array}{l}\text { V second } \\
\text { quarter }\end{array}$} & \multirow{10}{*}{$\begin{array}{c}\text { Contaminated soil- } \\
\text { Šabac* }\end{array}$} & \multirow{2}{*}{$\begin{array}{l}\text { Composite sample from the } \\
\text { rhizosphere of ragweed }\end{array}$} & Ragweed - aboveground \\
\hline & & & Ragweed - root \\
\hline & & \multirow{2}{*}{$\begin{array}{l}\text { Composite sample from the } \\
\text { rhizosphere of false acacia }\end{array}$} & False acacia- aboveground \\
\hline & & & False acacia - root \\
\hline & & \multirow{2}{*}{$\begin{array}{l}\text { Composite sample from the } \\
\text { rhizosphere of ailanthus }\end{array}$} & Ailanthus - aboveground \\
\hline & & & Ailanthus - root \\
\hline & & \multirow{2}{*}{$\begin{array}{l}\text { Composite sample from the } \\
\text { rhizosphere of mullein }\end{array}$} & Mullein- aboveground \\
\hline & & & Mullein- root \\
\hline & & \multirow{2}{*}{$\begin{array}{l}\text { Composite sample from the } \\
\text { rhizosphere of poplar }\end{array}$} & Poplar - aboveground \\
\hline & & & Poplar - root \\
\hline & Control soil - Šabac*** & Composite sample & \\
\hline
\end{tabular}

and suggests that its origin is quite likely natural and not the result of external contamination.

In the first year of the study, the above-ground parts of ragweed accumulated the highest levels of $\mathrm{Pb}, \mathrm{Cd}, \mathrm{Zn}, \mathrm{Cu}$, and As compared to false acacia and ailanthus (Table 4). These levels are close to or above the upper limit of phytotoxicity, which suggests that ragweed is a plant species resistant to $\mathrm{Pb}, \mathrm{Cd}, \mathrm{Zn}, \mathrm{Cu}$, and $\mathrm{As}$.

The levels of $\mathrm{Pb}, \mathrm{Cd}, \mathrm{Cu}, \mathrm{Zn}, \mathrm{Cr}, \mathrm{Ni}$, and As measured from the study year two to five in the rhizosphere of ragweed, ailanthus, false acacia, poplar, and mullein were in the following descending order: $\mathrm{Zn}>\mathrm{Pb}>\mathrm{Cu}>\mathrm{Cd}>\mathrm{As}>\mathrm{Ni}>\mathrm{Cr}$ (Table 5). Compared to the first-year measurements, these levels dropped by $36.83 \%$ for $\mathrm{Pb}, 25.48 \%$ for $\mathrm{Cd}, 15.73 \%$ for $\mathrm{Zn}, 23.32 \%$ for $\mathrm{Ni}, 96.13 \%$ for $\mathrm{Cr}$, and $36.85 \%$ for As. Unlike the rest, $\mathrm{Cu}$ showed no significant change in the rhizosphere levels between the first year and the subsequent years.

The standard deviations of the concentrations of $\mathrm{Pb}, \mathrm{Cd}$, $\mathrm{Zn}, \mathrm{Cu}, \mathrm{Ni}, \mathrm{Cr}$, and Asin the rhizosphere were as follows: 3,345.43-14,784.69 $\mathrm{mg} \mathrm{kg}^{-1}$; 408.34-520.20 mg kg-1; $29,652.01-56,285.24 \mathrm{mg} \mathrm{kg}^{-1} ; 1,425.40-2,150.96 \mathrm{mg} \mathrm{kg}^{-1}$; $5.40-8.55 \mathrm{mg} \mathrm{kg}^{-1} ; 3.02-9.14 \mathrm{mg} \mathrm{kg}^{-1} ; 134.60-402.62 \mathrm{mg} \mathrm{kg}^{-1}$, respectively.

Tables 6 and 7 show metal concentrations in plant rootsand above-ground parts of plants, respectively, in the years two, three, and five of the study. The retention of the heavy metals and As by the roots was as follows (in the descending order): ragweed $-\mathrm{Zn}>\mathrm{Pb}>\mathrm{Cu}>\mathrm{Cd}>\mathrm{As}>\mathrm{Cr}>\mathrm{Ni}$; ailanthus - $\mathrm{Zn}>\mathrm{Pb}>\mathrm{Cd}>\mathrm{Cu}>\mathrm{As}>\mathrm{Ni}>\mathrm{Cr}$; false acacia $\mathrm{Zn}>\mathrm{Pb}>\mathrm{Cu}>\mathrm{Cd}>\mathrm{A} \mathrm{s}>\mathrm{Cr}>\mathrm{Ni}$; p o p la r $\mathrm{Zn}>\mathrm{Pb}>\mathrm{Cu}>\mathrm{Cd}>\mathrm{As}>\mathrm{Cr}>\mathrm{N}$, and mullein - 
Table 3 Heavy metal and arsenic levels in soils in the first study year and calculated target and intervention levels to comply with regulatory limits in Serbia (34)

\begin{tabular}{lcccc}
\hline Parameter & Control soil in Belgrade & $\begin{array}{c}\text { Contaminated soil from } \\
\text { the study site }\end{array}$ & Target levels* & $\begin{array}{c}\text { Intervention } \\
\text { levels** }\end{array}$ \\
\hline $\mathrm{As}$ & $\mathrm{C}_{\text {soil }}\left(\mathrm{mg} \mathrm{kg}^{-1}\right)$ & $\mathrm{C}_{\text {soil }}\left(\mathrm{mg} \mathrm{kg}^{-1}\right)$ & $\left(\mathrm{mg} \mathrm{kg}^{-1}\right)$ & $\left(\mathrm{mg} \mathrm{kg}^{-1}\right)$ \\
\hline $\mathrm{Cd}$ & 9.20 & 978.60 & 17.95 & 34.05 \\
\hline $\mathrm{Cr}$ & $<0.70$ & $1,161.30$ & 0.48 & 7.21 \\
\hline $\mathrm{Cu}$ & 44.65 & $1,077.30$ & 61.94 & 235.37 \\
\hline $\mathrm{Ni}$ & 45.75 & $2,940.00$ & 19.43 & 102.54 \\
\hline $\mathrm{Pb}$ & 68.6 & 66.15 & 15.97 & 95.82 \\
\hline $\mathrm{Zn}$ & 61.10 & $36,330.00$ & 57.38 & 357.78 \\
\hline $\mathrm{C}$ & 185.20 & $101,220.00$ & 70.03 & 360.13
\end{tabular}

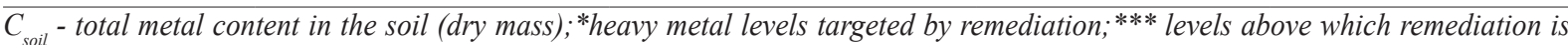
needed, calculated on the basis of clay content of $5.97 \%$ and the content of organic matter of $1.41 \%$ (34)

Table 4 Heavy metal and arsenic levelsin the aboveground plant parts in the first year of the study

\begin{tabular}{lcccccc} 
& \multicolumn{2}{c}{ Plant species from contaminated soil } & \multicolumn{2}{c}{ Plant species from control soil } \\
\cline { 2 - 7 } & Ragweed & $\begin{array}{c}\text { False } \\
\text { acacia }\end{array}$ & Ailanthus & Ragweed & False acacia & Ailanthus \\
\cline { 2 - 7 } & $\mathrm{mg} \mathrm{kg}^{-1 *}$ & $\mathrm{mg} \mathrm{kg}^{-1 *}$ & $\mathrm{mg} \mathrm{kg}^{-1 *}$ & $\mathrm{mg} \mathrm{kg}^{-1 *}$ & $\mathrm{mg} \mathrm{kg}^{-1 *}$ \\
\hline $\mathrm{Pb}$ & 248.4 & 98.1 & 77.0 & $<10$ & $<10$ & $<10$ \\
\hline $\mathrm{Cd}$ & 101.5 & 13.1 & 17.4 & $<2$ & $<2$ & $<2$ \\
\hline $\mathrm{Zn}$ & $1,382.4$ & 283.4 & 605.0 & 22.2 & 18.4 & 3.6 \\
\hline $\mathrm{Cu}$ & 42.1 & 12.0 & 7.7 & 10.0 & $<10$ & $<1.2$ \\
\hline $\mathrm{Ni}$ & $<10$ & $<10$ & $<10$ & $<10$ & $<10$ & $<10$ \\
\hline $\mathrm{As}$ & $<10$ & $<10$ & $<10$ & $<10$ & $<0.2$ & $<0.2$ \\
\hline
\end{tabular}

*dry mass

Table 5 Mean metal and arsenic levels in the rhizosphere

\begin{tabular}{|c|c|c|c|c|c|c|c|}
\hline Soil samples & $\begin{array}{c}\mathrm{Pb} \\
\mathrm{mg} \mathrm{kg}^{-1 *}\end{array}$ & $\begin{array}{c}\mathrm{Cd} \\
\mathrm{mg} \mathrm{kg}^{-1 *}\end{array}$ & $\underset{\mathrm{Zn}}{\mathrm{Zn} \mathrm{kg}}$ & $\begin{array}{c}\mathrm{Cu} \\
\mathrm{mg} \mathrm{kg}^{-1 *}\end{array}$ & $\begin{array}{c}\mathrm{Ni} \\
\mathrm{mg} \mathrm{kg}^{-1 *}\end{array}$ & $\begin{array}{c}\mathrm{Cr} \\
\mathrm{mg} \mathrm{kg}^{-1 *}\end{array}$ & $\begin{array}{c}\text { As } \\
\mathrm{mg} \mathrm{kg}^{-1 *}\end{array}$ \\
\hline Control soil, Šabac & 23.3 & 0.4 & 77.7 & 26.0 & 39.8 & 35.0 & 10.1 \\
\hline \multicolumn{8}{|l|}{ Contaminated soil (rhizosphere) } \\
\hline Ragweed & $8,794.5$ & 291.7 & $26,320.0$ & 505.1 & 55.2 & 43.2 & 269.9 \\
\hline False acacia & $28,398.3$ & $1,099.4$ & $110,117.7$ & $4,680.9$ & 50.1 & 45.7 & 759.7 \\
\hline Ailanthus & $31,380.3$ & $1,171.5$ & $130,100.0$ & $4,516.1$ & 49.9 & 41.4 & 763.7 \\
\hline Mullein & $22,468.0$ & 983.8 & $76,201.7$ & $3,296.6$ & 45.5 & 39.8 & 676.9 \\
\hline Poplar & $23,702.0$ & 780.6 & $83,769.3$ & $2,968.0$ & 52.9 & 38.3 & 619.4 \\
\hline $\begin{array}{l}\text { Contaminated soil mean for the study } \\
\text { years two to five }\end{array}$ & $22,948.6$ & 865.4 & $85,301.7$ & $3,193.3$ & 50.7 & 41.7 & 617.9 \\
\hline $\begin{array}{l}\text { Contaminated (composite) soil mean for } \\
\text { the study year one }\end{array}$ & $36,330.0$ & $1,161.3$ & $101,220.0$ & $2,940.0$ & 66.2 & $1,077.3$ & 978.6 \\
\hline Intervention level ${ }^{* *}$ & 357.8 & 7.2 & 360.1 & 102.5 & 95.8 & 235.4 & 34.1 \\
\hline
\end{tabular}

*dry mass; **levels above which remediation is needed, calculated on the basis of clay content of $5.97 \%$ and the content of organic matter of $1.41 \%(34)$ 
Table 6 Metal and arsenic rhizosphere levels by study years two to five

\begin{tabular}{|c|c|c|c|c|c|c|c|c|}
\hline Rhizosphere & Year & $\begin{array}{c}\text { Pb } \\
\mathrm{mg} \mathrm{kg}^{-1 *}\end{array}$ & $\begin{array}{c}\mathrm{Cd} \\
\mathrm{mg} \mathrm{kg}^{-1 *}\end{array}$ & $\begin{array}{c}\mathrm{Zn} \\
\mathrm{mg} \mathrm{kg}^{-1 *}\end{array}$ & $\begin{array}{c}\mathrm{Cu} \\
\mathrm{mg} \mathrm{kg}^{-1 *}\end{array}$ & $\begin{array}{c}\mathrm{Ni} \\
\mathrm{mg} \mathrm{kg}^{-1 *}\end{array}$ & $\begin{array}{c}\mathrm{Cr} \\
\mathrm{mg} \mathrm{kg}^{-1 *}\end{array}$ & $\begin{array}{c}\text { As } \\
\mathrm{mg} \mathrm{kg}^{-1 *}\end{array}$ \\
\hline Ragweed & II & $1,527.9$ & 50.0 & $3,122.2$ & 657.3 & 10.0 & 10.0 & 32.8 \\
\hline False acacia & II & $1,774.3$ & 703.3 & $6,530.6$ & 331.3 & 10.0 & 10.0 & 22.8 \\
\hline Ailanthus & II & 224.7 & 23.5 & 791.8 & 75.5 & 10.0 & 10.0 & 3.5 \\
\hline Mullein & II & $3,849.5$ & 326.2 & $26,705.0$ & 793.8 & 11.0 & 10.0 & 91.8 \\
\hline Poplar & II & $1,481.4$ & 313.3 & $3,858.0$ & 426.3 & 10.0 & 10.0 & 20.4 \\
\hline Ragweed & III & 852.8 & 52.3 & $2,086.5$ & 134.8 & 12.4 & 18.4 & 27.4 \\
\hline False acacia & III & 244.4 & 7.6 & 514.8 & 35.8 & 4.7 & 4.9 & 5.7 \\
\hline Ailanthus & III & 167.5 & 24.6 & $1,452.2$ & 98.5 & 4.4 & 7.6 & 13.0 \\
\hline Mullein & III & 515.9 & 3.1 & $1,166.0$ & 58.4 & 4.8 & 10.0 & 16.2 \\
\hline Poplar & III & $1,727.8$ & 69.1 & $2,586.4$ & 135.7 & 5.3 & 7.5 & 60.6 \\
\hline Ragweed & V & $2,203.2$ & 91.0 & $4,158.0$ & 214.9 & 7.3 & 5.7 & 38.2 \\
\hline False acacia & $\mathrm{V}$ & $1,112.8$ & 41.7 & $1,057.2$ & 95.9 & 8.2 & 13.2 & 9.8 \\
\hline Ailanthus & $\mathrm{V}$ & 916.2 & 29.0 & $1,106.6$ & 90.5 & 6.5 & 1.8 & 9.6 \\
\hline Mullein & $\mathrm{V}$ & 254.1 & 12.1 & 561.0 & 24.2 & 0.6 & 0.6 & 5.5 \\
\hline Poplar & $\mathrm{V}$ & 399.6 & 32.7 & 500.3 & 31.4 & 5.1 & 6.2 & 5.2 \\
\hline
\end{tabular}

* dry mass

Table 7 Metal and arsenic levels in the aboveground parts of the plants species by study years two to five

\begin{tabular}{lcccccccc}
$\begin{array}{l}\text { Aboveground } \\
\text { plant parts }\end{array}$ & Year & $\begin{array}{c}\mathbf{P b} \\
\mathbf{m g ~ k g}\end{array}$ & $\begin{array}{c}\mathbf{C d} \\
\mathbf{m g ~ k g}\end{array}$ & $\begin{array}{c}\mathbf{Z n} \\
\mathbf{m g ~ k g}\end{array}$ & $\begin{array}{c}\mathbf{C u} \\
\mathbf{m g ~ k g}\end{array}$ & $\begin{array}{c}\mathbf{N i} \\
\mathbf{m g ~ k g}\end{array}$ & $\begin{array}{c}\mathbf{C r} \\
\mathbf{m g ~ k g}^{-1 *}\end{array}$ & $\begin{array}{c}\mathbf{A s} \\
\mathbf{m g ~ k g}\end{array}$ \\
\hline Ragweed & II & 305.8 & 65.4 & $2,332.4$ & 87.2 & 10.0 & 10.0 & 7.1 \\
\hline False acacia & II & 28.6 & 5.3 & 254.6 & 793.8 & 10.0 & 10.0 & 1.2 \\
\hline Ailanthus & II & $1,804.4$ & 39.5 & $2,037.5$ & 32.1 & 10.0 & 10.0 & 2.0 \\
\hline Mullein & II & $1,840.8$ & 141.9 & $7,807.3$ & 368.2 & 10.0 & 10.0 & 37.8 \\
\hline Poplar & II & 289.7 & 111.6 & $3,358.4$ & 53.7 & 10.0 & 10.0 & 7.0 \\
\hline Ragweed & III & 95.4 & 59.1 & $1,298.0$ & 16.2 & 2.8 & 2.5 & 4.5 \\
\hline False acacia & III & 42.9 & 3.0 & 326.2 & 13.7 & 2.7 & 2.4 & 1.6 \\
\hline Ailanthus & III & 179.1 & 14.1 & 757.9 & 23.7 & 2.2 & 5.2 & 4.6 \\
\hline Mullein & III & 269.2 & 26.7 & $1,089.0$ & 38.0 & 3.4 & 7.5 & 8.9 \\
\hline Poplar & III & 57.3 & 28.1 & 302.0 & 8.6 & 1.3 & 2.7 & 2.1 \\
\hline Ragweed & V & 93.3 & 48.8 & 465.5 & 27.7 & 3.1 & 4.2 & 3.1 \\
\hline False acacia & V & 42.0 & 11.1 & 190.3 & 8.1 & 2.3 & 0.2 & 0.6 \\
\hline Ailanthus & V & 42.1 & 7.4 & 183.1 & 6.0 & 0.5 & 0.3 & 1.1 \\
\hline Mullein & V & 138.4 & 0.1 & 474.2 & 21.0 & 2.8 & 3.5 & 3.9 \\
\hline Poplar & V & 197.6 & 86.9 & 972.0 & 22.6 & 1.9 & 1.2 & 5.0 \\
\hline
\end{tabular}

*dry mass 
Table 8 Bioconcentration factor for the tested elements by plant species by the study year two to five

\begin{tabular}{lcccccccc}
\hline Plant & Year & Pb & $\mathbf{C d}$ & $\mathbf{Z n}$ & $\mathbf{C u}$ & $\mathbf{N i}$ & $\mathbf{C r}$ & $\mathbf{A s}$ \\
\hline Ragweed & II & 0.235 & 0.200 & 0.157 & 0.705 & 0.182 & 0.211 & 0.175 \\
\hline False acacia & II & 0.118 & 0.604 & 0.053 & 0.071 & 0.235 & 0.222 & 0.033 \\
\hline Ailanthus & II & 0.016 & 0.025 & 0.005 & 0.026 & 0.182 & 0.200 & 0.006 \\
\hline Mullein & II & 0.336 & 0.282 & 0.402 & 0.274 & 0.232 & 0.235 & 0.282 \\
\hline Poplar & II & 0.119 & 0.605 & 0.080 & 0.252 & 0.154 & 0.200 & 0.064 \\
\hline Ragweed & III & 0.048 & 0.098 & 0.040 & 0.706 & 0.238 & 0.482 & 0.051 \\
\hline False acacia & III & 0.008 & 0.009 & 0.006 & 0.009 & 0.097 & 0.151 & 0.011 \\
\hline Ailanthus & III & 0.004 & 0.021 & 0.012 & 0.016 & 0.116 & 0.230 & 0.015 \\
\hline Mullein & III & 0.025 & 0.005 & 0.020 & 0.023 & 0.112 & 0.312 & 0.025 \\
\hline Poplar & III & 0.054 & 0.074 & 0.028 & 0.034 & 0.119 & 0.249 & 0.082 \\
\hline Ragweed & V & 0.965 & 1.004 & 0.580 & 0.549 & 0.126 & 0.131 & 0.466 \\
\hline False acacia & V & 0.028 & 0.033 & 0.009 & 0.018 & 0.138 & 0.221 & 0.009 \\
\hline Ailanthus & V & 0.027 & 0.021 & 0.010 & 0.019 & 0.115 & 0.043 & 0.011 \\
\hline Mullein & V & 0.007 & 0.010 & 0.005 & 0.005 & 0.012 & 0.012 & 0.005 \\
\hline Poplar & V & 0.015 & 0.037 & 0.005 & 0.010 & 0.104 & 0.177 & 0.006 \\
\hline
\end{tabular}

$\mathrm{Zn}>>\mathrm{Pb}>>\mathrm{Cu}>\mathrm{Cd}>\mathrm{As}>\mathrm{Ni}>\mathrm{Cr}$. Retention by the aboveground parts was as follows: ragweed $\mathrm{Zn}>\mathrm{Pb}>\mathrm{Cd}>\mathrm{Cu}>\mathrm{Cr}>\mathrm{Ni}>\mathrm{As} ;$ ailanthus. $\mathrm{Zn}>\mathrm{Pb}>\mathrm{Cu}>\mathrm{Cd}>\mathrm{Cr}>\mathrm{Ni}>\mathrm{As}$; false acacia $\mathrm{Cu}>\mathrm{Zn}>\mathrm{Pb}>\mathrm{Cd}>\mathrm{Ni}>\mathrm{Cr}>\mathrm{As}$; poplar $\mathrm{Zn}>\mathrm{Pb}>\mathrm{Cd}>\mathrm{Cu}>\mathrm{As}>\mathrm{Cr}>\mathrm{Ni}$; and mullein $-\mathrm{Zn}>\mathrm{Pb}>\mathrm{Cu}>\mathrm{Cd}>\mathrm{As}>\mathrm{Cr}>\mathrm{Ni}$.

Overall, ragweed was the most effective in uptaking all seven elements (Table 8) and mullein was the most effective in translocation them (Table 9).
Poplar showed an increase in translocation as the study advanced (Table 9). This increasing translocation indicates that above-ground harvesting should be planned properly for slow phytoremediation, considering that poplar did not show hyperaccumulative properties. Earlier research on poplar trees showed that they can provide an efficient and economical method for the cleaning of soil contaminated with heavy metals $(18,36-42)$. Ailanthus, in turn, showed an increase in bioconcentration over the years (Table 8 ) and a decline in translocation (Table 9). As it mostly retained

Table 9 Translocation factor for the tested elements by plant species by the study year two to five

\begin{tabular}{lcccccccc}
\hline Parameter & Year & Pb & Cd & $\mathbf{Z n}$ & $\mathbf{C u}$ & $\mathbf{N i}$ & $\mathbf{C r}$ & $\mathbf{A s}$ \\
\hline Ragweed & II & 0.200 & 1.308 & 0.747 & 0.133 & 1.000 & 1.000 & 0.216 \\
\hline False acacia & II & 0.016 & 0.008 & 0.039 & 2.396 & 1.000 & 1.000 & 0.054 \\
\hline Ailanthus & II & 8.030 & 1.678 & 2.573 & 0.425 & 1.000 & 1.000 & 0.567 \\
\hline Mullein & II & 0.478 & 0.435 & 0.292 & 0.464 & 0.909 & 1.000 & 0.412 \\
\hline Poplar & II & 0.196 & 0.356 & 0.870 & 0.126 & 1.000 & 1.000 & 0.342 \\
\hline Ragweed & III & 0.112 & 1.130 & 0.622 & 0.120 & 0.226 & 0.136 & 0.164 \\
\hline False acacia & III & 0.176 & 0.395 & 0.634 & 0.383 & 0.574 & 0.490 & 0.281 \\
\hline Ailanthus & III & 1.069 & 0.573 & 0.522 & 0.241 & 0.500 & 0.684 & 0.354 \\
\hline Mullein & III & 0.522 & 8.613 & 0.934 & 0.651 & 0.708 & 0.750 & 0.552 \\
\hline Poplar & III & 0.033 & 0.407 & 0.117 & 0.063 & 0.245 & 0.360 & 0.035 \\
\hline Ragweed & V & 0.042 & 0.536 & 0.112 & 0.129 & 0.426 & 0.736 & 0.082 \\
\hline False acacia & V & 0.038 & 0.266 & 0.180 & 0.085 & 0.280 & 0.017 & 0.056 \\
\hline Ailanthus & V & 0.046 & 0.256 & 0.165 & 0.066 & 0.083 & 0.184 & 0.113 \\
\hline Mullein & V & 0.545 & 0.008 & 0.845 & 0.869 & 5.145 & 6.345 & 0.713 \\
\hline Poplar & V & 0.495 & 2.663 & 1.943 & 0.719 & 0.381 & 0.193 & 0.958 \\
\hline
\end{tabular}


the metals in the roots, ailanthus could be used for phytostabilisation of the contaminated loamy soil at the study site. The roots of false acacia poorly accumulated the metals (Table 8) and had little to transfer to the aboveground parts (Table 9).

The calculated bioconcentration (Table 8) and translocation factors (Table 9) indicate that ragweed could be used for phytostabilisation of soil contaminated by $\mathrm{Pb}$, $\mathrm{Cd}$, and As. Given that it hyperaccumulated $\mathrm{Cd}$, its use for phytoextraction should also considered. Because of its accumulation potential and because it causes severe allergic reactions in humans, ragweed can perhaps best serve as biomass material for combustion.

Mullein showed a decline in bioconcentration of the metals over the course of the study (Table 8) but it also showed increased translocation of $\mathrm{Pb}, \mathrm{Cu}, \mathrm{Ni}, \mathrm{Cr}$, and $\mathrm{As}$ (Table 9), which means that it could be used for phytoextraction, as reported earlier (43-45). Due to a high biomass production, it can improve soil organic contentand serve for re-vegetation (45).

The material properties of ragweed and mullein biomass relevant to their use as an energy source are listed in Table 10. The chemical composition of energy crops does not always meet the standards set for biofuels (46).

The ash content of a biomass affects handling and processing costs of the overall biomass energy conversion and knowing which biomass produces high or low ash content is key to selecting the right combustion and waste gas treatment method. Ragweed in our study had higher ash content than mullein, which suggests that a more suitable method for its combustion would be using the grid or fluidised bed technologies (21). Mullein, in turn, had a higher calorific value and lower ash content than ragweed, which suggests that mullein biomass has better characteristics as a source of energy.

\section{Heavy metals and As in ash}

Heavy metals clearly present an environmental problem when a biomass is burned. For one, combustion produces airborne particulate matter, and, two, ash in itself is polluted. Therefore, heavy metals in biomass fuels should be reduced. Biomass combustion produces several types of ash: bottom ash, cyclone fly ash, and filter fly ash (47). Figure 2 shows the concentrations of $\mathrm{Cr}, \mathrm{Ni}, \mathrm{Cu}, \mathrm{Cd}, \mathrm{Pb}$, and $\mathrm{As}$ in ash over the study years one, three, and five. $\mathrm{Ni}, \mathrm{Cr}$, and $\mathrm{Cu}$, which are lowly volatile, were concentrated in the bottom ash in both plants. In ragweed almost $100 \%$ of these heavy metals ended up in the bottom ash.

During combustion, As leaves the firebox and is recovered primarily on fly ash particles from the colder parts of the system or, if the stack sampling temperature remains in excess of $193{ }^{\circ} \mathrm{C}$ (the sublimation point of $\mathrm{As}_{2} \mathrm{O}_{3}$ ), a considerable percentage may end up in the stack gases (31). If the combustion temperature is below $550^{\circ} \mathrm{C}$, $\mathrm{As}_{2} \mathrm{O}_{5}$ is stable, and $\mathrm{AsO}$ is formed at temperatures higher than $850^{\circ} \mathrm{C}$.

Our study showed a decreasing trend in As levels in plant ashes over the years (Figure 2). Ragweed combustion produced about $2 \%$ of volatile As, whereas $100 \%$ remained in the bottom ash when mullein was burned.

The levels of $\mathrm{Pb}$ and $\mathrm{Zn}$ in the ash produced by mullein combustion at $550{ }^{\circ} \mathrm{C}$ were much higher than in the ragweed ash (Figure 2 and 3), which means that combustion of mullein biomass at $550{ }^{\circ} \mathrm{C}$ produces less volatile $\mathrm{Pb}$ and Zn forms.

Problems with ash utilisation for recycling purposes are to be expected at $\mathrm{Zn}$ and $\mathrm{Cd}$ levels above 0.08 and $0.0005 \mathrm{wt} \%$, respectively (21). Mean $\mathrm{Zn}$ and $\mathrm{Cd}$ levels in the mullein ashes were $17,878.20 \mathrm{mg} \mathrm{kg}^{-1}[17.88 \mathrm{wt} \%$ ] and $376.44 \mathrm{mg} \mathrm{kg}^{-1}[0.04 \mathrm{wt} \%$, respectively and in ragweed ashes $12,582.63 \mathrm{mg} \mathrm{kg}^{-1}\left[12.58 \mathrm{wt}^{0} \%\right]$ and $516.17 \mathrm{mg} \mathrm{kg}^{-1}$ [0.05 wt\%], respectively, which is much higher than the recommended value for recycling.

Environmentally the most relevant metals like $\mathrm{Cd}, \mathrm{Pb}$, and $\mathrm{Zn}$ will concentrate in the filter fly ash (47). Filter fly ash is highly hazardous and has to be disposed of in a safe way or redirected to industrial heavy metal recovery (47). In the ashes of mullein and ragweed, $\mathrm{Pb}, \mathrm{Cd}$, and $\mathrm{Zn}$ concentrations decreased over the years.

\section{CONCLUSIONS}

Through bioaccumulation, plants can concentrate heavy metals at levels thousands of times higher than in the soil. The contaminated plant biomass can be digested or burned to reduce its volume, and the resulting material can be recycled as an "ore" to recover the heavy metals. If metal recycling is not economically justified, the relatively small amount of ash left after combustion (compared to the original biomass or the extremely large volume of contaminated soil) can be disposed of in an appropriate manner.

Table 10 Biomass technical analysis

\begin{tabular}{lccccc}
\multirow{2}{*}{ Plant } & \multirow{2}{*}{ Ash } & \multirow{2}{*}{ Ash } & V & LHV & HHV \\
\cline { 2 - 7 } & $550{ }^{\circ} \mathrm{C}$ & $815{ }^{\circ} \mathrm{C}$ & $\%$ & $\mathrm{~kJ} \mathrm{~kg}^{-1}$ & $\mathrm{~kJ} \mathrm{~kg}^{-1}$ \\
\hline Ragweed /contaminated soil & 9.28 & 4.41 & 72 & 15,112 & 16,469 \\
\hline Mullein / contaminated soil & 6.41 & 5.60 & 79 & 18,078 & 19,735 \\
\hline Ragweed/control soil & 6.16 & 2.25 & 74 & 19,507 & 20,884 \\
\hline
\end{tabular}

$V$-volatile matter; LHV - low heating value; HHV - high heating value 


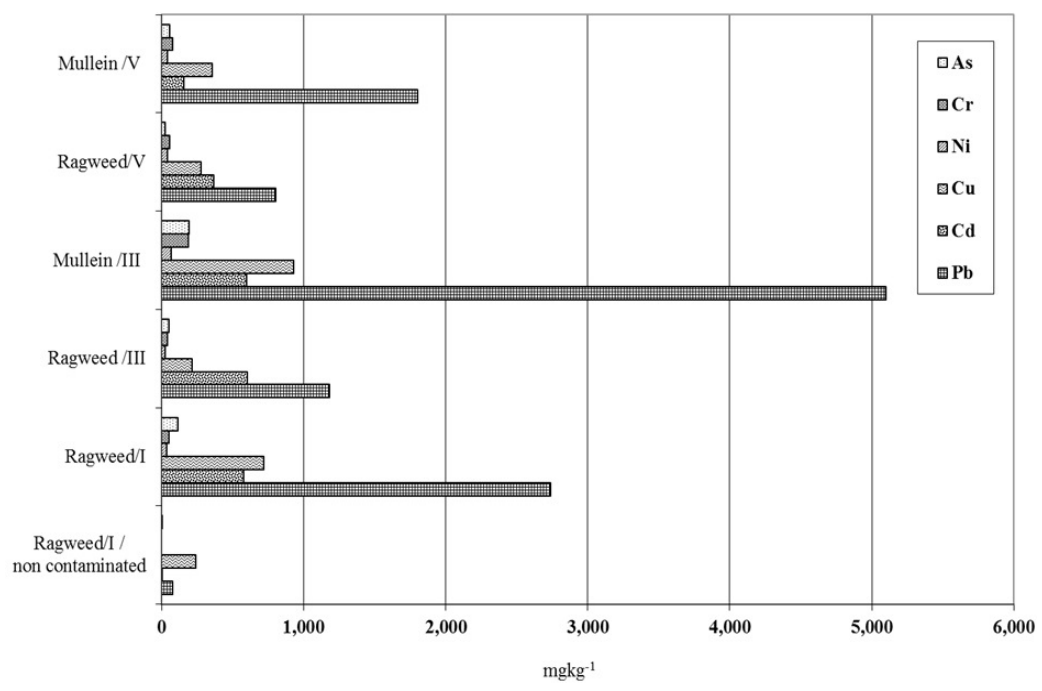

Figure 2 Total $\mathrm{As}, \mathrm{Cr}, \mathrm{Ni}, \mathrm{Cu}, \mathrm{Cd}$, and $\mathrm{Pb}$ in plant ashes

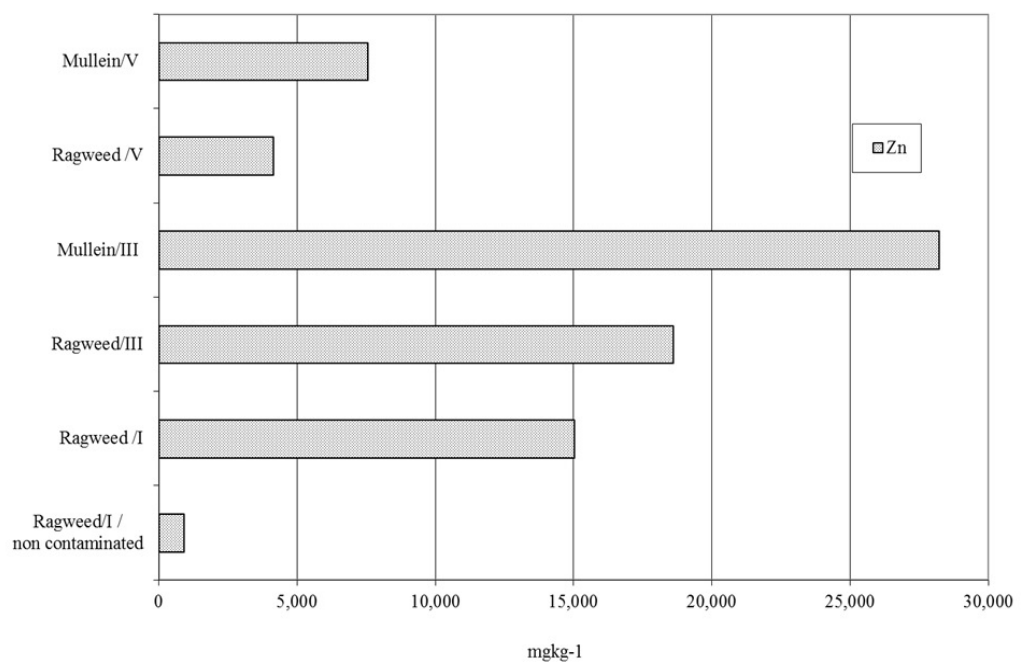

Figure 3 Total $\mathrm{Zn}$ in plant ashes

In our study, ragweed showed the highest ash and heavy metal bioconcentrations. Mullein showed higher tolerance to metals, lower ash content, and higher calorific value than ragweed. Because mullein efficiently transported metal pollutants into the above-ground parts and because it fits well the desired characteristics for its use as a biomass, it is our plant of choice for further bioremediation use at the polluted industrial site.

\section{Acknowledgements}

We would like to thank the Belgrade Institute of Public Health, Serbia for financial and technical support in chemical analyses.

\section{REFERENCES}

1. Mühlbachová G, Száková J, Tlustoš P. The heavy metal availability in long-term polluted soils as affected by EDTA and alfalfa meal treatments. Plant Soil Environ 2012;58:5516. [displayed 4 August 2016]. Available at http://www. agriculturejournals.cz/publicFiles/78767.pdf

2. Vidaković-Cifrek Ž, Tkalec M, Šikić S, Tolić S, Lepeduš H, Pevalek-Kozlina B. Growth and photosynthetic responses of Lemna minor L. exposed to cadmium in combination with zinc or copper. Arh Hig Rada Toksikol 2015;66:141-52. doi: 10.1515/aiht-2015-66-2618

3. Wong MH. Ecological restoration of mine degraded soils, with emphasis on metal contaminated soils. Chemosphere 2003;50:775-80. doi: 10.1016/S0045-6535(02)00232-1

4. Freitas H, Prasad MNV, Pratas J. Plant community tolerant to trace elements growing on the degraded soils of Sao Domingos mine in the south east of Portugal: environmental implications. Environ Int 2004;30:65-72. doi: 10.1016/ S0160-4120(03)00149-1

5. Del Rio-Celestino M, Font R, Moreno-Rojas R, De HaroBailon A. Uptake of lead and zinc by wild plants growing on contaminated soils. Ind Crop Prod 2006;24:230-37. doi: 10.1016/j.indcrop.2006.06.013 
6. Moors HME, DijkemaPJG. Embedded industrial production systems: Lessons from waste management in zinc production. Technol Forecast Soc 2006;73:250-65.doi: 10.1016/j. techfore.2004.03.006

7. Bozkurt S. Assessment of the Long-Term Transport Processes and Chemical Evolution in Waste Deposits. [PhD thesis]. Stockholm: Royal Institute of Technology; 2000.

8. Bolan N, Kunhikrishnanc A, Thangarajana R, Kumpiened J, Parke J, Makinof T, Kirkhamg BM, Scheckelh K. Remediation of heavy metal(loid)s contaminated soils - To mobilize or to immobilize? J Hazard Mater 2014;266:141-66. doi: 10.1016/j.jhazmat.2013.12.018

9. Rosselli W, Keller C, Boschi K. Phytoextraction capacity of trees growing on a metal contaminated soil. Plant Soil 2003;256:265-72. doi: 10.1023/A:1026100707797

10. Madejón P, Murillo JM, Marañón T, Cabrera F, López R. Bioaccumulation of $\mathrm{As}, \mathrm{Cd}, \mathrm{Cu}, \mathrm{Fe}$ and $\mathrm{Pb}$ in wild grasses affected by the Aznalcollar mine spill (SW Spain). Sci Total Environ 2002;290:105-20. doi: 10.3184/095422914X14141 630849689

11. Yoon J, Cao X, Zhou Q, Ma QL. Accumulation of Pb, Cu and $\mathrm{Zn}$ in native plants growing on a contaminated Florida site. Sci Total Environ 2006;368:456-64. doi: 10.1016/j scitotenv.2006.01.016

12. ZayedMA, Terry N. Chromium in the environment: factors affecting biological remediation. Plant Soil 2003;249:139-56. doi: 10.1023/A:1022504826342

13. Baker AJM, Brooks RR. Terrestrial higher plants which hyperaccumulate metal elements: a review of their distribution, ecology, and phytochemistry. Biorecovery 1989;1:81-126.

14. Antonkiewicz J, Para A. The use of dialdehyde starch derivatives in the phytoremediation of soils contaminated with heavy metals. Int J Phytoremediation 2016;18:245-50. doi: 10.1080/15226514.2015.1078771

15. Robinson B, Schulin R, Nowak B, Roulier S, Menon M, Clothier B, Green S, Mills T. Phytoremediation for the management of metal flux in contaminated sites. For Snow Landsc Res 2006;80:221-34.

16. España-Gamboa E, Mijangos-Cortes J, Barahona-Perez L, Dominguez-Maldonado J, Hernandez-Zarate G, AlzateGaviriaLj. Vinasses: characterization and treatments. Waste Manag Res 2011;29:1235-50. doi: 10.1177/0734242X 10387313

17. Pulford ID, Watson C. Phytoremediation of heavy metal contaminated land by trees - a review. Environ Int 2003;29:529-40. doi: 10.1016/S0160-4120(02)00152-6

18. Vamerali T, Bandiera M, Coletto L, Zanetti F, Dickinson MN, Mosca G. Phytoremediation trials on metal- and arseniccontaminated pyrite wastes (Torviscosa, Italy). Environ Pollut 2009;157:887-94. doi 10.1016/j.envpol.2008.11.003

19. Obernberger I, Supancic K. Possibilities of ash utilisation from biomass combustion plants. In: Proceedings of the $17^{\text {th }}$ European Biomass Conference \& Exhibition, From Research to Industry and Markets; 29 June - 3 July 2009; Hamburg, Germany. Florence: ETA-Florence Renewable Energies; 2009. p. 2373-84.

20. Van Eijk RJ, Obernberger I, Supancic K. Options for increased utilization of ash from biomass combustion and co-firing, 30102040-PGR/R\&E 11-2142, IEA Bioenergy Task 32, Deliverable D4, 2012. [displayed 05 May 2014].
Available at http://www.ieabcc.nl/publications/Ash_ Utilization_KEMA.pdf

21. Obernberger I, Brunner T, Bärnthaler G. Chemical properties of solid biofuels - significance and impact. Biomass Bioenerg 2006;30:973-82. doi: 10.1016/j.biombioe.2006.06.011

22. JovanovićLj, Marković M, Stojiljković D, Radovanović M, Cupać S, Despotović S, Ilić S, Drazić D, Bojović S. Usage of crops and wild plants growing on polluted soil as an energy source. In: Procceeding of the $2^{\text {nd }}$ World Conference on Biomass for Energy, Industry and Climate Protection; 10-14 May 2004; Roma, Italy 2004. ETA-Florence, Italy and WIPMunich, Germany 2004. p. 2529-33.

23. Avramov L, Nakalamić A, Todorović N, Petrović N, Žunić D. Climate of the vineyard zones and the associated vine varieties of Yugoslavia. J AgricSci (Belgrade) 2000;45:29-35. doi: 10.2298/JAS0601061P

24. U.S. Environmental Protection Agency (US EPA). Method 3050b; Acid Digestion of Sediments, Sludges, and Soils. Washington (DC): U.S. EPA; 1996.

25. U.S. Environmental Protection Agency (US EPA). Method 200.7; Trace Elements in Water, Solids and Biosolids by Inductively Coupled Plasma-Atomic Emission Spectrometry, ICP-OES. Washington (DC): U.S. EPA; 2001.

26. SRPS EN ISO 11885:2011 - Water quality - Determination of selected elements by inductively coupled plasma optical emission spectroscopy (ICP-OES). Belgrade: Institute for Standardization of Serbia; 2011.

27. SRPS EN ISO 11969:2009 - Water quality - Determination of arsenic - Atomic absorption spectrometric method (hydride technique). Belgrade: Institute for Standardization of Serbia; 2009.

28. EN 14780:2011 - Solid biofuels - Methods for sample preparation. Brussels: European Standardization Organizations; 2011.

29. EN 14775:2011 - Solid biofuels - Determination of ash content. Brussels: European Standardization Organizations; 2011.

30. ISO 1171:2010 - Solid mineral fuels - Determination of ash. Geneva: International Organization for Standardization; 2010.

31. Dare P, Gifford H, Hooper JR, Clemens HA, Damiano FL, Gong D, Matheson WT. Combustion performance of biomass residue and purpose grown species. Biomass Bioenerg 2001;21:277-87. doi: 10.1016/S0961-9534(01)00039-3

32. EN 14918:2009 - Solid biofuels - Determination of calorific value. Brussels: European Standardization Organizations; 2009.

33. SRPS EN 15104:2012 - Solid biofuels - Determination of total content of carbon, hydrogen and nitrogen - Instrumental methods. Belgrade, Institute for Standardization of Serbia; 2012.

34. Uredba o programu sistemskog praćenja kvaliteta zemljišta, indikatorima za ocenu rizika od degradacije zemljišta i metodologiji za izradu remedijacionih programa.[Regulation on a program of systematic monitoring of soil quality, indicators for assessing the risk of soil degradation and methodology for development of remediation programs, in Serbian]. Službeni glasnik RS 88/2010.

35. Crnković MD. Analiza uticaja prisutnih teških metala I policikličnih aromatičnih ugljovodonika na kvalitet zemljišta $\mathrm{u}$ Beogradu [Analysis of the impact of present trace metals and polycyclic aromatic hydrocarbons on the soil quality in 
Belgrade, in Serbian]. [MSc thesis]. Belgrade: University of Belgrade, Faculty of Technology and Metallurgy; 2005.

36. Mertens J, Vervaeke P, De Schrijver A, Luyssaert S. Metal uptake by young trees from dredged brackish sediment: limitations and possibilities for phytoextraction and phytostabilisation. Sci Total Environ 2004;326:209-15. doi: 10.1016/j.scitotenv.2003.12.010

37. Laureysens I, Blust R, De Temmerman L, Lemmens C, Ceulemans R. Clonal variation in heavy metal accumulation and biomass production in a poplar coppice culture: I. Seasonal variation in leaf, wood and bark concentrations. Environ Pollut 2004;131:485-94. doi: 10.1016/j. envpol.2004.02.009

38. Sebastiani L, Scebba F, Tognetti R. Heavy metal accumulation and growth responses in poplar clones Eridano (Populusdeltoides ${ }^{\times}$maximowiczii) and $\mathrm{I}-214\left(P .{ }^{\times}\right.$ euramericana) exposed to industrial waste. Environ Exp Bot 2004;52:79-88. doi: 10.1016/j.envexpbot.2004.01.003

39. Laureysens I, Pellis A, Willems J, Ceulemans R. Growth and production of a short rotation coppice culture of poplar. III. Second rotation results. Biomass Bioenerg 2005;29:10-21. doi: 10.1016/j.biombioe.2005.02.005

40. Yang X, Feng Y, He Z, StoffellaPJ. Molecular mechanisms of heavy metal hyperaccumulation and phytoremediation. J Trace Elem Med Biol 2005;18:339-53. doi: 10.1016/j. jtemb.2005.02.007

41. Brunner I, Luster J, Günthardt-Goerg MS, Frey B. Heavy metal accumulation and phytostabilisation potential of tree fine roots in a contaminated soil. Environ Pollut 2008;152:55968. doi: 10.1016/j.envpol.2007.07.006

42. Wang Z, MacFarlane WD. Evaluating the biomass production of coppiced willow and poplar clones in Michigan, USA, over multiple rotations and different growing conditions. Biomass Bioenerg 2012:46:380-8. doi: 10.1016/j. biombioe.2012.08.003

43. Kfayatullah Q, Tahir Shah M, Arfan M. Biogeochemical and environmental study of the chromite-rich ultramafic terrain of Malakand area, Pakistan. Environ Geol 2001;40:1482-6. doi: 10.1007/s002540100374

44. Freitas H, Prasad MNV, Pratas J. Analysis of serpentinophytes from north-east of Portugal for trace metal accumulationrelevance to the management of mine environment. Chemosphere 2004;54:1625-42. doi: 10.1016/j. chemosphere.2003.09.045

45. Arslan H, Güleryüz G, Leblebici Z, Kırmızı S, Aksoy A. Verbascum bombyciferum Boiss. (Scrophulariaceae) as possible bio-indicator for the assessment of heavy metals in the environment of Bursa, Turkey. Environ Monit Assess 2010;163:1105-13. doi 10.1007/s10661-009-0820-1

46. Antonkiewicz J, Kołodziej B, Bielińska E. The use of reed canary grass and giant miscanthus in the phytoremediation of municipal sewage sludge. Environ Sci Pollut Res Int 2016;23:9505-17. doi: 10.1007/s11356-016-6175-6

47. Narodoslawsky M, Obernberger I. From waste to raw material - the route from biomass to wood ash for cadmium and other heavy metals. J Hazard Mater 1996:50:157-68. doi: 10.1016/0304-3894(96)01785-2

\section{Fitoremedijacijski potencijal divljih biljnih vrsta koje rastu na zemljištu kontaminiranom teškim metalima}

Fitoremedijacija je tehnologija kojom se pomoću biljaka zemljišta čiste od zagađivala, uključujući metale. S obzirom na to da se stvara biomasa bogata ekstrahiranim toksičnim metalima, potrebno ju je dodatno obraditi. Cilj ovoga petogodišnjeg istraživanja bio je procijeniti potencijal sljedećih divljih biljnih vrsta za proizvodnju biomase i za uklanjanje teških metala iz zagađenog zemljišta: topole (Populus ssp.), pajasena (Ailanthus glandulosa L.), bagrema (Robinia pseudoacacia L.), ambrozije (Artemisia artemisiifolia L.) i divizme (Verbascum thapsus L.). Prosječno onečišćenje zemljišta olovom, kadmijem, cinkom, bakrom, niklom i kromom te arsenom u zoni korijena bilo je 22.948,6 mg kg-1, 865,4 mg kg-1, $85.301,7 \mathrm{mg} \mathrm{kg}^{-1}, 3.193,3 \mathrm{mg} \mathrm{kg}^{-1}, 50,7 \mathrm{mg} \mathrm{kg}^{-1}$ i $41,7 \mathrm{mg} \mathrm{kg}^{-1}$ te $617,9 \mathrm{mg} \mathrm{kg}^{-1}$. Također su izmjereni sadržaj vlage $\mathrm{i}$ pepela nastalog paljenjem biljaka, sadržaj $\mathrm{Pb}, \mathrm{Cd}, \mathrm{Zn}, \mathrm{Cu}, \mathrm{Ni}, \mathrm{Cr}$ i As u nadzemnim dijelovima biljaka i njihovu pepelu te bruto toplotna vrijednost. Fitoekstrakcijski i fitostabilizacijski potencijal utvrđen je za divizmu i ambroziju na temelju faktora biokoncentracije (BCF) i faktora translokacije (TF). Divizma se je pokazala kao hiperakumulator kadmija, a pokazala je i veću gornju toplotnu moć $\left(19.735 \mathrm{~kJ} \mathrm{~kg}^{-1}\right) \mathrm{u}$ odnosu na ambroziju (16.469 kJ kg-1). Rezultati ovog istraživanja upućuju na to da divizma ima potencijala za fitoekstrakciju i za proizvodnju biomase, a da ambrozija može biti djelotvorna u remedijaciji zemljišta fitostabilizacijom.

KLJUČNE RIJEČI: ambrozija; arsen;bakar; biomasa; cink;divizma; faktor biokoncentracije; faktor translokacije; fitoekstrakcija; fitostabilizacija; hiperakumulator; kadmij; krom; nikal; olovo; rizosfera 